\title{
GROŽIO TERAPEUTO NUGAROS RAUMENŲ NUOVARGIO VERTINIMAS ATLIEKANT KŪNO PROCEDŪRĄ
}

\author{
Danguolè Grūnovienė $\dot{1}^{1}$ Miglẻ Bartašiūtè ${ }^{1}$, Albinas Grūnovas², Kristina Poderienè2 \\ ${ }^{1}$ Kauno kolegija, ${ }^{2}$ Lietuvos sporto universitetas
}

Raktažodžiai: kaulų ir raumenų sistema, ergonomika, nuovargis, miotonometrija, infraraudonoji spektroskopija

\begin{abstract}
Santrauka
Grožio terapeutu praktikoje gana anksti pasireiškia nusiskundimai dèl kaulų ir raumenų sistemos. Tokių nusiskundimų atsiradimą didžiaja dalimi lemia ergonominès priežastys: stovimas darbas, nepatogi kūno padètis ir kt., o grožio terapeuto darbo vietos pritaikymas individualiai pagal specialisto antropometrinius duomenis ir darbo specifiką išlieka aktuali problema. Šio darbo tikslas buvo nustatyti darbo vietos įtaką grožio terapeuto nugaros raumenų subjektyviam nuovargiui, tonuso ir kraujotakos pokyčiams atliekant kūno procedūrą ant standartinio ir individualizuoto aukščio kušečių. Šešios tiriamosios atliko 20 min. trukmès nugaros masažą ant standartinès aukščio ir individualizuoto aukščio masažo kušečių. Subjektyvus nugaros raumenų nuovargis ir tonusas buvo vertinami prieš ir po procedūros atlikimo, bei visos procedūros metu registruojamas deguonies įsotinimas. Grožio terapeutai jautè mažesnį subjektyvų tiesiamụjų nugaros raumenų nuovargị procedūrą atlikdami ant individualizuoto aukščio kušetès, toki patị kairès pusès trapecinio raumens nuovargị ir didesnị dešinio trapecinio raumens subjektyvų nuovargi. Tiesiamujų nugaros raumenų tonusas padidèjo mažiau atliekant kūno procedūrą ant individualizuoto aukščio kušetès. Statinius nugaros raumenų darbo ịpročius turinčios grožio terapeutès pasižymėjo nugaros tiesiamojo raumens deguonies įsotinimo mažejimais kūno procedūrą atliekant ant standartinio aukščio kušetès. Dinaminio nugaros raumenų darbo ịpročius turinčioms grožio terapeutèms buvo būdingas didesnis nugaros tiesiamojo raumens deguonies įsotinimas atliekant procedūrą ant individualizuoto aukščio kušetès.
\end{abstract}

\section{Ivadas}

Grožio terapeutų praktikoje gana anksti pasireiškia nusiskundimai dèl kaulų ir raumenų sistemos sutrikimų, tokių kaip nugaros, pečių, kaklo, viršutinių galūnių skausmai. Europos darbuotojų saugos ir sveikatos darbe užtikrinimo komisijos tyrimo duomenimis (2014 m.), net 70 proc. grožio srityje dirbančių specialistų turèjo sveikatos sutrikimų dèl netinkamų darbo sąlygų bei ilgų darbo valandų [5]. Dauguma grožio srities specialistų skundèsi pervargimu darbe, rankų ir riešų, kaklo ir pečių srities skausmais, viršutinès ar apatinès nugaros dalies skausmais $[1,2]$. Stovimas darbas, nepatogi kūno padètis, netinkamai pritaikyta darbo vieta sukelia fizini nuovargị, o tai yra viena iš nugaros skausmą sukeliančiu priežasčių. Todèl grožio terapeuto darbo vietos pritaikymas individualiai pagal specialisto antropometrinius duomenis ir darbo specifiką yra aktuali problema.

Tyrimo tikslas: nustatyti darbo vietos įtaką grožio terapeuto nugaros raumenų subjektyviam nuovargiui, tonuso ir kraujotakos pokyčiams atliekant kūno procedūrą ant standartinio ir individualizuoto aukščio kušečių.

\section{Tyrimo objektas ir metodika}

Tyrime dalyvavo šešios tiriamosios, turinčios kvalifikaciją atlikti klasikinį kūno masažą, jos atliko 20 min. trukmès nugaros masažą ant standartinès $74 \mathrm{~cm}$. aukščio masažo kušetès ir tokią pat procedūrą ant masažo kušetès, kurios aukštis buvo individualizuotas pagal kiekvienos tiriamosios ūgị. Individualizuotas masažo kušetės aukštis buvo nustatomas pagal atstumą nuo grindų iki tiriamosios riešo. Abi tyrimo dienas prieš atliekant kūno procedūrą ir po procedūros atlikimo dešimties balų vizualine analogine skale buvo vertinamas kairès ir dešinès pusès trapecinio bei juosmeninès dalies nugaros tiesiamojo raumenų subjektyvus nuovargis. Taip pat prieš kūno procedūros atlikimą ir po jos, gęstančių raumens virpesių matavimu ir analizès principo sistema MYOTON-3 buvo matuojamas raumenų tonusas, kaip objektyvus analogiškų nugaros raumenų nuovargio rodiklis (Vain, 1995; Roja ir kt., 2006). Neinvazinès artimosios infraraudonosios spektroskopijos (NAIS) metodu visos procedūros metu buvo registruojamas deguonies ịsotinimas $\mathrm{StO}_{2}$ nugaros tiesiamojo raumens juosmeninès dalies dešinès pusès T 4 - T 5 slankstelių lygmenyje. Buvo skaičiuojami rodiklių vidurkiai ir standartinès paklaidos, naudotas 95 proc. patikimumo lygmuo $(\mathrm{p}<0,5)$. 


\section{Rezultatai}

Visoms tiriamosioms, remiantis antropometriniais duomenimis, standartinès masažo kušetės aukštis buvo per žemas. Aukščio skirtumas tarp standartinès ir individualaus aukščio masažo kušečių buvo nuo $7 \mathrm{~cm}$ iki $14 \mathrm{~cm}$.

Abiejų pusių nugaros tiesiamojo raumens subjektyvaus nuovargio skirtumas buvo didesnis procedūrą atliekant ant standartinio aukščio kušetès $(1,67 \pm 042$ balo - kairès ir $2,33 \pm 0,71$ balo - dešinès), nei ant individualizuoto aukščio

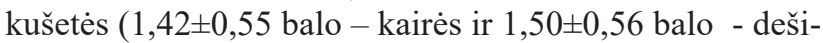
nès). Tačiau skirtumai nebuvo statistiškai patikimi $(\mathrm{p}>0,05)$. Lyginant kairę ir dešinę puses stebime statistiškai patikimai didesnị dominuojančios (dešinès) pusès nuovargio skirtumą $(p<0,05)$. Kairès pusès trapecinio raumens vargstamumas buvo vienodas kūno procedūrą atliekant tiek ant standartinio, tiek ant individualizuoto aukščio kušetès $(0,83 \pm 0,40$ balo ir $0,83 \pm 0,17$ balo atitinkamai). Dešinès pusès trapecinio raumens vargstamumas buvo didesnis kūno procedūrą atliekant ant individualizuoto aukščio kušetès $(0,83 \pm 0,31$ balo- kairès ir $1,33 \pm 0,33$ balo - dešinès) $(\mathrm{p}<0,05)$ ( 1 pav. $)$

Atliekant procedūrą ant standartinio aukščio kušetès kairès pusés nugaros tiesiamojo raumens tonusas padidèjo 7,6 $\pm 0,64$ proc., kai analogišką procedūrą atliekant ant indivi-

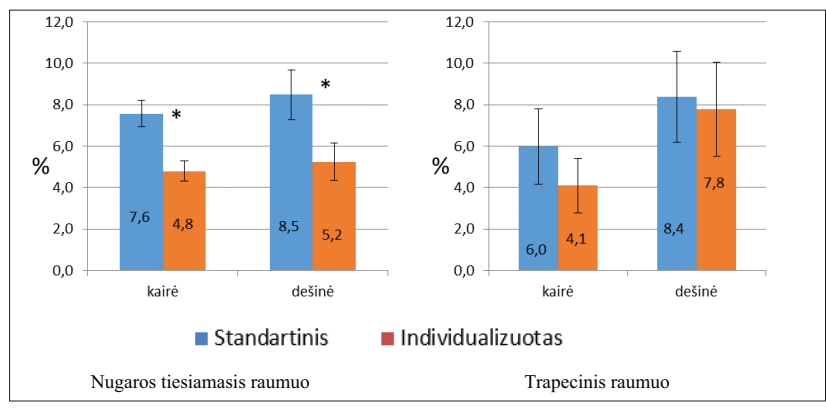

1 pav. Nugaros raumenų subjektyvaus nuovargio vertinimo prieš ir po masažo procedūros atlikimą skirtumas (Subjektyvaus nuovargio skirtumas $=$ nuovargis po - nuovargis prieš)

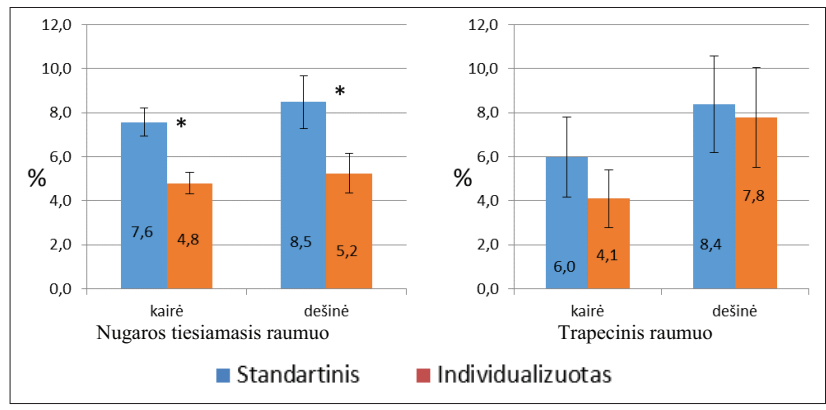

2 pav. Kairès ir dešinès pusès nugaros tiesiamojo ir trapecinio raumenų tonuso skirtumai prieš ir po procedūros atlikimo. $(*$ - skirtumas statistiškai patikimas, $p<0,05)$ dualizuoto aukščio kušetės tonusas padidèjo $4,8 \pm 0,49$ proc. Skirtumas statistiškai patikimas $(\mathrm{p}<0,05)$. Atliekant procedūrą ant standartinio aukščio kušetès dešinès pusès nugaros tiesiamojo raumens tonusas padidejo $8,5 \pm 1,19$ proc., kai analogišką procedūrą atliekant ant individualizuoto aukščio kušetès tonusas padidejo $5,2 \pm 0,89$ proc. Skirtumas statistiškai patikimas $(p<0,05)(2$ pav. $)$. Kairès pusès trapecinio raumens tonusas padidejo $6,0 \pm 1,82$ proc. atliekant procedūrą ant standartinio aukščio kušetès, o analogišką procedūrą atliekant ant individualizuoto aukščio kušetès tonusas padidejjo 4,1 $\pm 1,31$ proc. Atliekant procedūrą ant standartinio aukščio kušetès dešinès pusès trapecinio raumens tonusas padidèjo $8,4 \pm 2,18$ proc., kai analogišką procedūrą atliekant ant individualizuoto aukščio kušetès tonusas padidejo 7,8 $\pm 2,27$ proc. Skirtumai nebuvo statistiškai patikimi ( $\mathrm{p}>0,05$ ).

Raumens deguonies įsotinimo kitimai priklause nuo grožio terapeutèms būdingų ịpročių, kai atliekant kūno procedūrą vyravo statinis arba dinaminis liemens darbas. Dviem tiriamosioms buvo būdingas nugaros raumenų statinio darbo tipas, o keturioms - dinaminio darbo tipas. 3 paveiksle pateiktos nugaros tiesiamojo raumens deguonies įsotinimo kitimo tipinès kreivès atliekant kūno procedūrą.

Grožio terapeutèms atliekant ilgiau trunkantị statišką nugaros raumenų darbą kraujotakos intensyvumas ir deguonies įsotinimas mažèjo. Ypač tai buvo būdinga atliekant statinị darbą, kai nugara palinkusi ị priekị. (3 A pav.) Tiriamosioms,

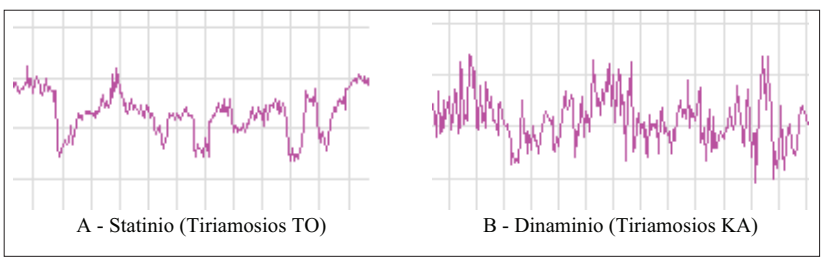

3 pav. Statinio ir dinaminio nugaros tiesiamojo raumens darbo deguonies įsotinimo tipinès kreivès atliekant kūno procedūrą

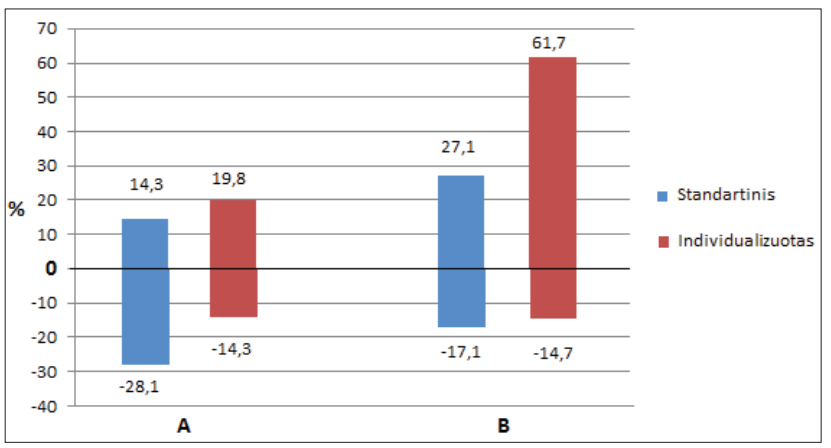

4 pav. Statinio (A) ir dinaminio (B) darbo tipo nugaros tiesiamojo raumens deguonies ịsotinimo kitimo ribos minimumas ir maksimumas, kuriose svyravo kraujotaka atliekant kūno procedūrą ant skirtingo aukščio masažo kušečių 
kurioms buvo būdingas dinaminis nugaros raumenų darbas, (t.y. santykinis judesių nepertraukiamumas) reikšmingų, ilgiau trunkančių kraujotakos ir deguonies įsotinimo kritimų nebuvo stebima. (3 B pav.)

Grožio terapeutès, kurioms buvo būdingas statinis nugaros raumenų darbas, atliekant kūno procedūrą linkusios dažniau fiksuoti nugarą statinèje padètyje. Vykdant užduotį ant standartinès (žemesnio nei rekomenduojama aukščio) masažo kušetės, nugarą palenkus ị priekị, fiksuodavo daug dažniau ir ilgesniam laikui. Tai atsispindejo ir deguonies ịsotinimo rodikliuose: deguonies ịsotinimas kūno procedūrą atliekant ant standartinio aukščio kušetės mažèdavo vidutiniškai iki 28,1 proc. nuo pradinio lygio. Tuo tarpu tą pačią procedūrą vykdant ant individualiai pritaikytos kušetès šis mažèjimas buvo 14,3 proc. (4 A pav.) Grožio terapeutès, kurioms buvo būdingas dinaminis nugaros raumenų darbas, nepasižymėjo dideliais deguonies įsotinimo nugaros tiesiamajame raumenyje mažejimais: 17,1 proc. ant standartinès masažo kušetè ir 14,7 proc. ant individualizuotos masažo kušetès. Šioms tiriamosioms buvo būdingas deguonies ịsotinimo didèjimas, sąlygotas dinaminio raumens darbo. Vykdant kūno procedūrą ant standartinio aukščio kušetės deguonies įsotinimas didèdavo iki 27,1 proc., o ant individualizuotos masažo kušetės net iki 61,7 proc. (4 B pav.)

Prisitaikant prie nepatogios darbo aplinkos yra naudojami įvairūs kompensaciniai judesiai. Tyrime dalyvavusios tiriamosios, kurioms standartinio aukščio kušete buvo gerokai per žema, prisitaikydavo prie jos aukščio kojas laikydamos plačioje pozicijoje. Kai kojos klubų plotyje, keliai nukreipti ị išorę, o svoris pernešamas nuo kojos ant kojos, išvengiama statinès darbo pozos. Raitelio pozoje liemuo lenkiamas ne stuburo sąskaita, o per klubų sąnarius. Tokiu būdu sumažinama nugaros tiesiamujų raumenų itampa [4]. Kūno procedūrą atliekant tokioje kompensacinèje padètyje mažeja nugaros judesių amplitudè. Todèl tiriamosios, atlikdamos kūno procedūrą ant patogios individualizuoto aukščio kušetès didesne amplitude, dažniau judino nugarą ir tai atsispindi deguonies ịsotinimo didejjime.

\section{Išvados}

1. Grožio terapeutai, atlikdami kūno procedūrą ant individualizuoto aukščio kušetės, jautė mažesnị subjektyvų tiesiamųų nugaros raumenų nuovargi, nei šią procedūrą vykdant ant standartinio aukščio kušetès, tokị patị kairès pusès trapecinio raumens nuovargị ir didesnị dešinio trapecinio raumens subjektyvų nuovargị.

2. Grožio terapeutų tiesiamujjų nugaros raumenų tonusas padidejo mažiau atliekant kūno procedūrą ant individualizuoto aukščio kušetès.

3. Statinius nugaros raumenų darbo įpročius turinčios grožio terapeutės pasižymèjo nugaros tiesiamojo raumens deguonies įsotinimo mažèjimais kūno procedūrą atliekant ant standartinio aukščio kušetès. Dinaminio nugaros raumenų darbo ịpročius turinčioms grožio terapeutèms buvo būdingas didesnis nugaros tiesiamojo raumens deguonies įsotinimas atliekant procedūrą ant individualizuoto aukščio kušetės.

\section{Literatūra}

1. Alexandra T, Dimitra T, Athena L, Merekoulias G, Evangelos CA. Musculoskeletal disorders among cosmetologists 2009.

2. Bradshaw L, Harris-Roberts J, Bowen J, Rahman S, Fishwick D. (). Self-reported work-related symptoms in hairdressers. Occupational Medicine 2011;61, 328-334.

https://doi.org/10.1093/occmed/kqr089

3. Beilman GJ. Blondet J. Near - infrared spectroscopy - derived tissue oxygen saturation in battle field injuries: a case series report. World Journal of Emergency Surgery 2009;10:1-7. https://doi.org/10.1186/1749-7922-4-25

4. Enoka MR, Duchateau J. Muscle fatigue: Muscle fatigue: what, why and how it influences muscle function, J Physiol 2008; $1: 11-23$.

https://doi.org/10.1113/jphysiol.2007.1394775.

5. Occupational health and safety in the hairdressing sector. European Agency for Safety and Health at Work (2014). Prieiga per internetą: https://osha.europa.eu/lt/tools-and-publications/ publications/literature_reviews/occupational-health-and-safety-in-the-hairdressing-sector/view

6. Roja Z, Kalkis V, Vain A. et al. Assessment of skeletal muscle fatigue of road maintenance workers heart rate monitoring and myotonometry. Journal of Occupational Medicine and Toxicology 2006; 1(20):1-9.

7. Vain A. Role of skeletal muscle tone and elasticity in the workability restoration of male cross-country skiers. Acta Academiae Olympiquae Estoniae 2002; 10:95-108.

\section{ASSESSMENT OF SPINAL MUSCLE FATIGUE OF BEAUTY THERAPIST DURING THE BODY PROCEDURE}

\section{Grūnovienė, M. Bartašiūtė, A. Grūnovas, K. Poderienė}

Key words: bone and muscular system, ergonomics, fatigue, myotonometry, infrared spectroscopy.

Summary

In the practice of beauty therapists complaints about the bone and muscular system appear in early work practice. The appearance of such complaints is largely due to ergonomic reasons: standing work, uncomfortable body position, etc. Adapting the workplace for beauty therapist individually according to the anthropometric data of the specialist and the specificity of the work remains relevant problem. The aim of this work was to determine the influence of the workplace on the subjective fatigue of the spinal muscle of the beauty therapist, changes in tone and blood flow during the body procedure on standard and customized height massage couch. Six subjects performed 20 minutes long back massage on 
standard and individualized heights massage couch. Subjective muscle fatigue and tone were evaluated before and after the procedure, and oxygen saturation was recorded throughout the procedure. Beauty therapists felt less subjective torsional fatigue of the spinal muscles by applying a custom height couch, the same fatigue on the left side of the trapezius, and a greater subjective fatigue of the right trapezius muscle. The tone of the spinal muscle was increased performing procedure on a custom height couch. Beauty therapists with static back musculoskeletal work habits were marked by lowering the oxygen saturation of the spinal muscle in the body performing procedure on standard couch. Beauty therapists with dynamic spinal muscle work habits were characterized by higher oxygen saturation of erector spinae performing procedure on a customized massage couch.

Correspondence to: mbartasiute@gmail.com

Gauta 2017-10-30 